\title{
CHARACTERIZATION OF LEAF FEATURES IN SOME BLACKBERRY GENOTYPES COLLECTED FROM THE BLACK SEA REGION
}

\author{
Fatma Alan ${ }^{1}$, Aydin Uzun ${ }^{1 *}$, Hasan Pinar ${ }^{1}$ \\ ${ }^{1}$ Erciyes University Department of Horticulture, Kayseri, Turkey
}

Current Trends in

Natural Sciences

\begin{abstract}
In this study, morphological characterization studies regarding to leaf characteristics (leaf length, leaf width, leaf cross section shape, leaf edge waviness, swelling between leaf veins, leaf tooth depth, dominant leaflet number, leaf shape, green color intensity on the upper part of the leaf and brightness on the upper part of the leaf) were carried out in some blackberry genotypes collected from the Black Sea Region of Turkey, according to the definition lists of UPOV (International Association for the Protection of New Plant Varieties). The measurements and observations made were transformed into feature scores, and using these scores, dendrogram and principal component analysis (PCA) related to morphological features were obtained.

In the dendrogram obtained according to the morphological characterization data, the similarity level between the materials was determined between 0.50-1.00 and the average similarity coefficient was found as 0.75. The dendrogram consists of 2 main clusters ( $A$ and B). According to the dendrogram, genotypes obtained from Samsun (Çarşamba 1), Samsun (Çarşamba 2) and Ordu (Gülyalı), Bartın (Center) and Rize (Küçükçayır) regions were found to be the closest genotypes with 1.00 similarity level. In addition, as a result of the principal component analysis (PCA), the similarities and differences within the blackberry genotypes were clearly revealed. It was determined that they consisted of three main groups and two outer groups in their distribution on the two-dimensional plot.As a result of the study, it was determined that there is a certain level of variation between blackberry genotypes. The data obtained from this study will help to protect the diversity and to evaluate it with different studies.
\end{abstract}

Keywords: Blackberry, genetic diversity, morphological characterization

\section{INTRODUCTION}

The geographical location and ecological situation of Turkey has created a great plant growing potential and diversity (Ağaoğlu, 2006). Among these, berry fruits have a special importance for our country (Avc1, 2013). Genus such as strawberry (Fragaria), raspberry and blackberry (Rubus), mulberry (Morus), currant and gooseberry (Ribes), European cranberrybush (Viburnum), blueberry (Vaccinium), rosehip (Rosa) and related species are important berries. (Ağaoğlu and Gerçekcioğlu, 2013). Blackberry; It consists of plants in the form of a bush within the Rubus L. genus of the Rosaceae family (A ğaoğlu and Gerçekçioğlu, 2013). It is cultivated in Turkey and in many parts of the world. It grows naturally in the temperate regions of the northwest of Asia, in the mountains of North Africa, Europe, North America and South America (Moore and Clark, 1993). Most of the cultivars originate from North America. Blackberry is a fruit with beneficial effects on human 
health, and it has been reported to have antioxidant and anticarcinogenic effects (Aines and Byers, 2003).

Turkey is located within the gene center of many fruit and vegetable species grown in the world and has a richness of species and varieties. As the reasons for this; It is shown that ecological conditions are suitable, Turkey is located on the migration routes and Anatolia has been the center of civilization since the first ages of history (Sar1, 2010).

Genetic diversity studies are stated to be a stage in which variations between individuals and groups or between individuals and populations are analyzed with a special method or a combination of different methods. Data are used in different ways by converting them into numerical values. Various data sets are used to analyze genetic diversity in plants. These can be listed as DNA-based data that can reliably reveal biochemical and differences obtained by pedigree, morphological, isoenzyme analysis. Since each of these data sets contain different information, the selection of analysis methods; It may differ according to the purpose of the study and the desired details (Mohammadi and Prasanna, 2003).

In this study, morphological characterization studies were carried out in terms of leaf characteristics in samples collected from blackberry populations naturally grown in the Black Sea Region in the north of Turkey. The information obtained from the study is important in terms of determining the morphological variation, protecting the genotypes and guiding the studies on blackberry.

\section{MATERIALS AND METHODS}

In the study, 12 blackberry genotypes collected from the Black Sea Region were used. Morphological characterization studies regarding to leaf characteristics (leaf length, leaf width, leaf cross section shape, leaf edge waviness, swelling between leaf veins, leaf tooth depth, dominant leaflet number, leaf shape, green color intensity on the upper part of the leaf and brightness on the upper part of the leaf) were carried out in some blackberry genotypes collected from the Black Sea Region of Turkey, according to the definition lists of UPOV (Table 1). The measurements and observations made were transformed into feature scores and using these scores, the data on morphological features were analyzed with NTSYS-pc 2.11X computer package program (Rohlf, 1998). The genetic similarity levels between blackberry genotypes were calculated with the simple matching (SM) method. The dendrogram was obtained in the SAHN module using the UPGMA grouping analysis method. A cophenetic correlation number ' $r$ ' was calculated by performing the Mantel test (Mantel, 1967), showing how well the dendrogram represents the similarity data. In addition, the distribution of blackberry genotypes on a two-dimensional plot was obtained by performing principal components analysis (PCA).

\section{RESULTS AND DISCUSSION}

Leaf characteristics in blackberry genotypes were revealed using 11 UPOV criteria (Table 1). In terms of these characteristics, variations were determined between genotypes in general. Leaf height was determined as long in 5 genotypes, short in 4 genotypes and medium in 3 genotypes. Leaf width was found to be medium in $83 \%$ of genotypes. The leaf cross-section was U-shaped in $58 \%$ of the genotypes. It was observed that the leaf margins were irregular teeth in all genotypes. Dominant leaflet number was triple in $75 \%$ of the genotypes and five $25 \%$. Sar1 (2010) examined the leaves according to UPOV criteria in the study he conducted in Tokat province. In terms of the cross section of the leaves, $77.3 \%$ of the genotypes are classified as U-shape and $22.7 \%$ as V-shape; in terms of the toothedness at the leaf margins, $6.8 \%$ were grouped as regular teeth and $93.2 \%$ as irregular teeth. They found $82 \%$ of the dominant leaflet number is triple while $18 \%$ is five. The 
results of our study and the results of Sar1 (2010) generally overlap. The differences between them are due to the genetic characteristics of the genotypes and the ecological conditions of region they studied.

Table 1. Identification of leaf characteristics in blackberry genotypes according to UPOV criteria

\begin{tabular}{|c|c|c|c|c|c|c|c|c|c|c|c|c|}
\hline $\begin{array}{l}\text { G. } \\
\text { No }\end{array}$ & $\begin{array}{l}\text { Collected } \\
\text { Area }\end{array}$ & LH & LW & LCSS & LEW & SLV & TLE & LTD & DLN & LS & LSGC & LSG \\
\hline 1 & $\begin{array}{l}\text { Amasya- } \\
\text { Merzifon }\end{array}$ & $3=$ Short & $5=$ Medium & $2=\mathrm{V}$ Form & $2=$ Medium & $5=$ Medium & $\begin{array}{c}2=\text { Irregular } \\
\text { teeth }\end{array}$ & $5=$ Medium & $1=$ Triple & $\begin{array}{l}2=\text { =Mutual } \\
\text { alignment }\end{array}$ & $7=$ Dark & $5=$ Medium \\
\hline 2 & $\begin{array}{l}\text { Bartın- } \\
\text { Merkez }\end{array}$ & $7=$ Long & $5=$ Medium & $2=\mathrm{V}$ Form & $2=$ Medium & $1=$ Too Weak & $\begin{array}{c}2=\text { Irregular } \\
\text { teeth }\end{array}$ & $5=$ Medium & $2=5 \mathrm{~s}$ & $\begin{array}{c}3= \\
\text { Alternative }\end{array}$ & $7=$ Dark & $5=$ Medium \\
\hline 3 & $\begin{array}{l}\text { Kastamonu- } \\
\text { Küre }\end{array}$ & $3=$ Short & $3=$ Narrow & $1=\mathrm{U}$ Form & $2=$ Medium & $5=$ Medium & $\begin{array}{c}2=\text { Irregular } \\
\text { teeth }\end{array}$ & $5=$ Medium & $1=$ Triple & $\begin{array}{l}2=\text { Mutual } \\
\text { alignment }\end{array}$ & $5=$ Medium & $5=$ Medium \\
\hline 4 & Ordu-Gülyalı & $3=$ Short & $5=$ Medium & $2=\mathrm{V}$ Form & $2=$ Medium & $3=$ Zayıf & $\begin{array}{c}2=\text { Irregular } \\
\text { teeth }\end{array}$ & 5=Medium & $1=$ Triple & $\begin{array}{c}3= \\
\text { Alternative }\end{array}$ & $5=$ Medium & $5=$ Medium \\
\hline 5 & $\begin{array}{c}\text { Rize- } \\
\text { Küçükçayır }\end{array}$ & $7=$ Long & $5=$ Medium & $1=\mathrm{U}$ Form & $1=$ Weak & 3=Zayıf & $\begin{array}{c}2=\text { Irregular } \\
\text { teeth }\end{array}$ & $3=$ Shallow & $1=$ Triple & $\begin{array}{l}2=\text { Mutual } \\
\text { alignment }\end{array}$ & $7=$ Dark & $5=$ Medium \\
\hline 6 & $\begin{array}{l}\text { Samsun- } \\
\text { Atakum }\end{array}$ & $5=$ Medium & $5=$ Medium & $1=\mathrm{U}$ Form & $2=$ Medium & $5=$ Medium & $\begin{array}{c}2=\text { Irregular } \\
\text { teeth }\end{array}$ & $3=$ Shallow & $1=$ Triple & $\begin{array}{l}2=\text { Mutual } \\
\text { alignment }\end{array}$ & $5=$ Medium & $5=$ Medium \\
\hline 7 & $\begin{array}{c}\text { Samsun- } \\
\text { Carșamba } 1\end{array}$ & $5=$ Medium & $5=$ Medium & $1=\mathrm{U}$ Form & $2=$ Medium & $5=$ Medium & $\begin{array}{c}2=\text { Irregular } \\
\text { teeth }\end{array}$ & $3=$ Shallow & $1=$ Triple & $\begin{array}{l}2=\text { Mutual } \\
\text { alignment }\end{array}$ & $5=$ Medium & $5=$ Medium \\
\hline 8 & $\begin{array}{c}\text { Samsun- } \\
\text { Çarșamba } 2\end{array}$ & $5=$ Medium & $5=$ Medium & $1=\mathrm{U}$ Form & $2=$ Medium & $5=$ Medium & $\begin{array}{c}2=\text { Irregular } \\
\text { teeth }\end{array}$ & $3=$ Shallow & $1=$ Triple & $\begin{array}{l}2=\text { Mutual } \\
\text { alignment }\end{array}$ & $5=$ Medium & $5=$ Medium \\
\hline 9 & $\begin{array}{l}\text { Trabzon- } \\
\text { Akçaabat }\end{array}$ & $7=$ Long & $5=$ Medium & $2=\mathrm{V}$ Form & $1=$ Weak & $1=$ Too Weak & $\begin{array}{c}2=\text { Irregular } \\
\text { teeth }\end{array}$ & $3=$ Shallow & $2=5 \mathrm{~s}$ & $\begin{array}{l}2=\text { Mutual } \\
\text { alignment }\end{array}$ & $7=$ Dark & $5=$ Medium \\
\hline 10 & $\begin{array}{l}\text { Trabzon- } \\
\text { Vakfikebir }\end{array}$ & $7=$ Long & $5=$ Medium & 1=U Form & $1=$ Weak & $5=$ Medium & $\begin{array}{c}2=\text { Irregular } \\
\text { teeth }\end{array}$ & $3=$ Shallow & $1=$ Triple & $\begin{array}{l}2=\text { Mutual } \\
\text { alignment }\end{array}$ & $7=$ Dark & $7=$ Strong \\
\hline 11 & Tokat-Merkez & $3=$ Short & $3=$ Narrow & $1=\mathrm{U}$ Form & $1=$ Weak & $1=$ Too Weak & $\begin{array}{c}2=\text { Irregular } \\
\text { teeth }\end{array}$ & $5=$ Medium & $1=$ Triple & $\begin{array}{l}2=\text { Mutual } \\
\text { alignment }\end{array}$ & $5=$ Medium & $5=$ Medium \\
\hline 12 & $\begin{array}{l}\text { Zonguldak- } \\
\text { Merkez }\end{array}$ & $7=$ Long & $5=$ Medium & $2=\mathrm{V}$ Form & $2=$ Medium & $1=$ Too Weak & $\begin{array}{c}2=\text { Irregular } \\
\text { teeth }\end{array}$ & 5=Medium & $2=5 \mathrm{~s}$ & $\begin{array}{c}3= \\
\text { Alternative }\end{array}$ & $7=$ Dark & $5=$ Medium \\
\hline
\end{tabular}

G. No: Genotype No; LH: Leaf height; LW: Leaf width; LCSS: Leaf cross section shape, LEW: Leaf edge waviness; SLV: Swelling between leaf veins; TLE: Toothing on the leaf edge; LTD: Leaf thread depth; DLN: Dominant leaflet number; LS: Leaf shape; LSGC: Leaf surface green color intensity; LSG: Leaf top surface gloss

In our study, leaf surface green color intensity was found in dark for $50 \%$ of genotypes and medium in half of the genotypes. Ochieng et al. (2019) determined this feature in blackberries in their study in Kenya as follows. For all the germplasm sampled, For all the germplasm sampled, $31 \%$ had their leaves mostly green with minor symptoms of biotic and abiotic stress (B/AS), 23\% had apparent majority of leaves green but with obvious symptoms of B/AS, $16 \%$ had obvious symptoms of B / AS with more than $50 \%$ of leaves green.

Analyzes were made regarding these morphological data obtained in our study. The cophenetic correlation coefficient, which reveals the correlation between the similarity indices and the dendrogram, was calculated as $r=0.82$. This situation indicates that there is a good correlation between similarity indexes and dendrogram.

In the dendrogram obtained, the similarity levels of the genotypes were determined between 0.50 and 1.00 (Figure 1). Genotypes were divided into 2 main clusters (A and B) and main cluster B consisted of two subgroups (B1 and B2). In main cluster A, genotypes collected from Rize (Küçükçayır), Bartın (Center) and Trabzon (Vakfıkebir) regions were included. Main Cluster B, Samsun (Carsamba 1), Samsun (Carsamba 2), Ordu (Gülyal1), Tokat (Center), Zonguldak (Center) in B1 subgroup, Trabzon (Akçaabat), Amasya (Merzifon), Samsun (Atakum) and genotypes taken from Kastamonu (Küre) regions have been established. According to the dendrogram, Samsun (Wednesday 1), Samsun (Wednesday 2) and Ordu (Gülyal1) genotypes; Bartın (Center) and Rize (Küçükçayır) genotypes showed the same characteristics. The similarity levels of genotypes obtained from Kastamonu (Küre) and Samsun (Atakum) and Zonguldak (Center) and Tokat (Center) regions were 0.83 and similarity levels of the genotypes from Amasya (Merzifon) and Trabzon (Akçaabat) and Trabzon (Vakfıkebir), Bartın (Center) and Rize (Küçükçayır) regions were 0.75 . 


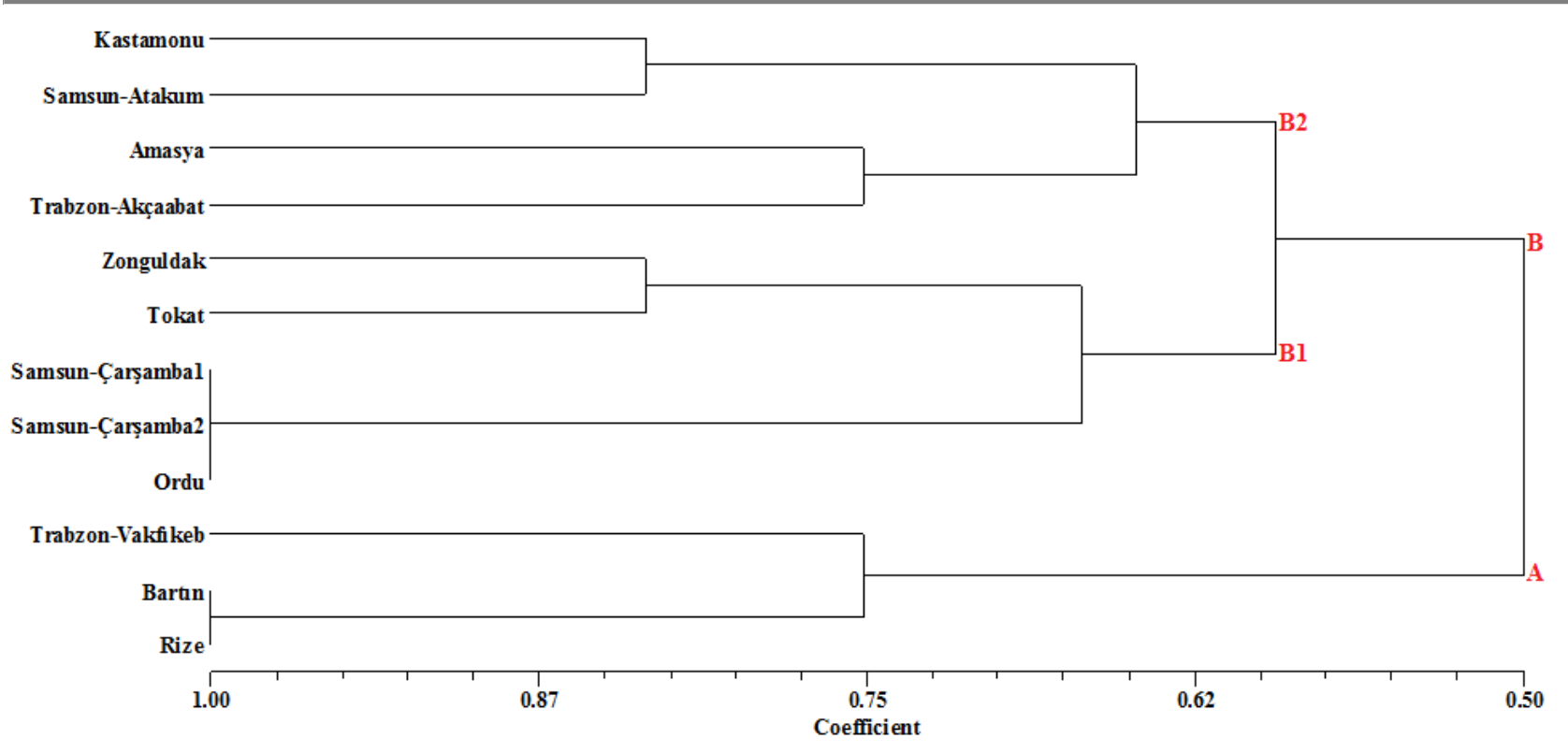

Figure 1. Dendrogram generated as a result of morphological characterization in blackberry genotypes

Sar1 (2010) used 44 wild blackberry genotypes collected from different areas covering eight provinces of the Black Sea Region in his study. In the dendrogram created of blackberry genotypes, it was determined that the genotypes were gathered under two main groups. Sedighi and Rahimmalek (2015) used morphological markers to assess the genetic diversity in populations of $R$. hyrcanus and $R$. discolor species in Iran. According to the morphological analysis results observed a relationship between genetic variability and geographic distribution in some Rosaceace species, and significant morphological variation between most genotypes.

The distribution of blackberry genotypes on the two-dimensional plot was determined by performing principal components analysis (PCA) with the obtained data (Figure 2). In the twodimensional distribution graph obtained, the similarities and differences among the blackberry genotypes were clearly revealed, and 3 main groups (A, B, C) and 2 outgroups were formed. In the first group (A) genotypes from Trabzon (Vakfikebir), Rize (Küçükçayır) and Bartın (Center), in the second group (B) Samsun (Carsamba 1), Samsun (Carsamba 2), Ordu (Gülyalı), Tokat (Center) and Zonguldak (Center), in the third group (C) genotypes from Amasya (Merzifon) and Trabzon (Akçaabat) regions were located. The genotypes obtained from Kastamonu (Küre) and Samsun (Atakum) regions were nested separately.

Due to the high level of similarity between the members of the first group (A), the cluster is squeezed into a very narrow area. Since the similarities between the second and third groups (B and C) were not higher than those of the first group, this clustering was also less sparse. In the twodimensional plot, it was determined that the similarities and differences between genotypes were expressed on a graph similar to the dendrogram. 


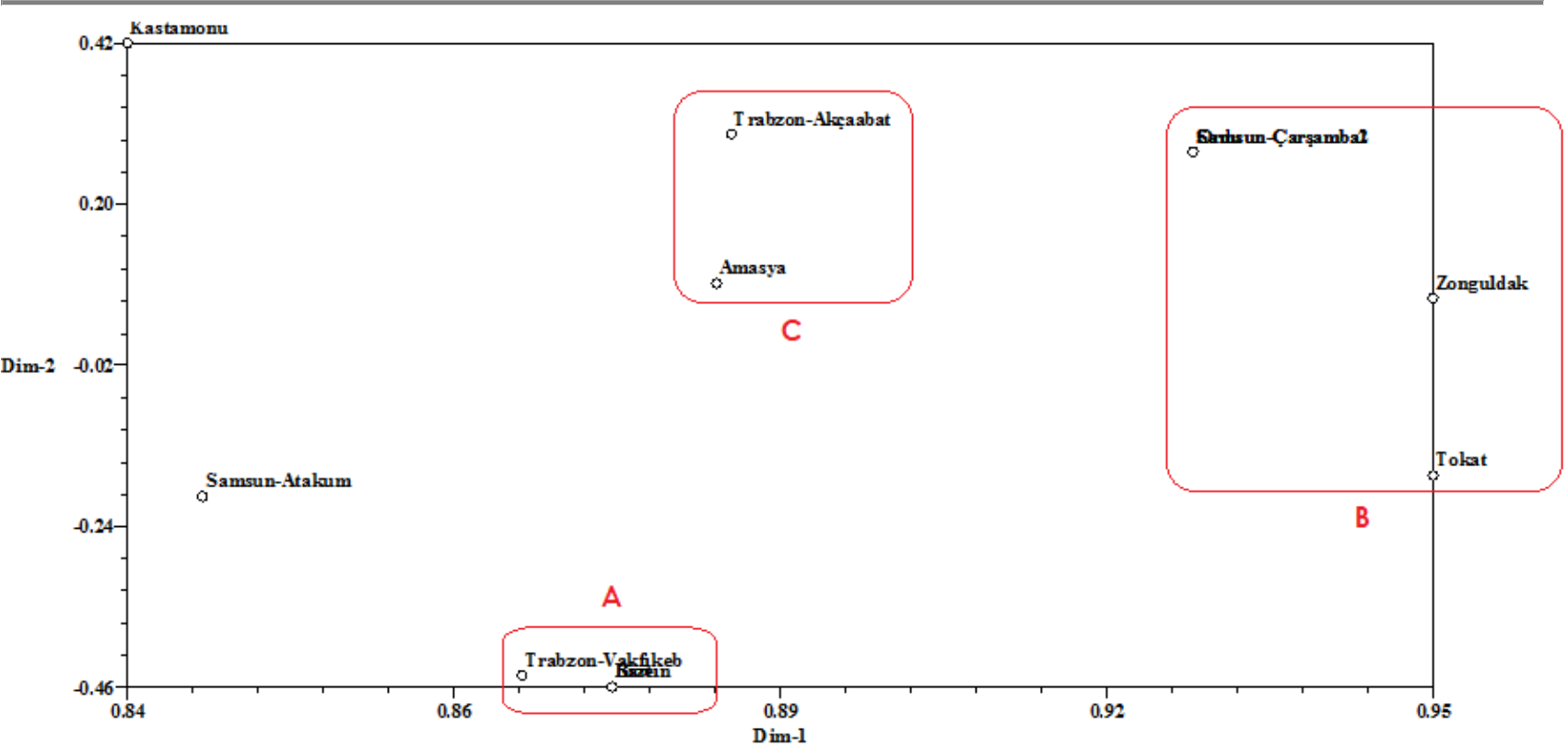

Figure 2. Two dimensional plot obtained from morphological characterization results in blackberries

\section{CONCLUSIONS}

It is important to preserve the morphological diversity obtained from this study and to evaluate it with different studies. The variation revealed is a valuable asset for breeding studies and other research. In order for these not to be lost in nature and to carry future generations, they should be evaluated with studies.

\section{ACKNOWLEDGEMENTS}

We would like to thank the Scientific Research Projects Unit of Erciyes University for their support to the project coded FDK-2016-6731, which is the subject of this study.

\section{REFERENCES}

Ağaoğlu, S. Y., Eyduran, S. P., ve Çelik, M., 2006. Bazı Böğürtlen Çeşitleri Ayaş (Ankara) Koşullarına Adaptasyonu Üzerinde Araştırmalar [Studies on the Adaptation of Some Blackberry Cultivars to Ayas (Ankara) Conditions], II. Ulusal Üzümsü Meyveler Sempozyumu, Gaziosmanpaşa Üniversitesi, Ziraat Fakültesi, Bahçe Bitkileri Bölümü, Tokat, p, 151-156 (in Turkish).

Ağaoğlu., S., Gerçekcioğlu, R., 2013. Üzümsü Meyveler [Berry Fruits]. Tomurcukbağ Ltd. Şti. Eğitim Yayınları, Ankara, p: 651 (in Turkish).

Aines, K., Byers, P. L., 2003. 'Growing Blackberries in Missouri', Department of Fruit Science College of Natural and Applied Sciences Missouri State University Mountain Grove, Missouri http://mtngrv.missouristate.edu/Publications/-b39.pdf, (E.T.16.032019)

Avcı., S. 2013. Bazı Böğürtlen Çeşitlerinin Malatya Ekolojik Koşullarına Adaptasyonu [Adaptation of Some Blackberry Varieties to Malatya Ecological Conditions]. Kahramanmaraş Sütçü İmam Üniversitesi, Fen Bilimleri Enstitüsü, Bahçe Bitkileri Anabilim Dalı, Yüksek Lisans Tezi, Kahramanmaraş, p: 56 (in Turkish).

Mantel, N., 1967. The detection of disease clustering and a generalized regression approach. Cancer Res. 27, 209-220.

Mohammadi, S.A., Prasanna., B.M. 2003. Analysis of Genetic Diversity in Crop Plants Salient Statistical Tools and Considerations. Crop Sci. 43,1235-1248.

Moore, J.N., Clark, J.R., 1993. Arapaho Erect Thornless Blackberry, Hortscience, 28 (8), 861-862.

Ochieng, J.A., Gesimba, R.M., Oyoo, M.E., Korir, P.C., Owuoche, J.O., Miheso, M. 2019. Morphological characterization of blackberry (Rubus subgenus Rubus Watson) genetic resources in Kenya. African Journal of Plant Science, 13 (11), 297-308. 
Sar1, S. 2010. Orta ve Doğu Karadeniz Bölgesi Doğal Popuslasyonundan Toplanan Böğürtlen Genotiplerinin UPOV Kriterlerine Göre Morfolojik Olarak Tanımlanması [Morphological Identification of Blackberry Genotypes Collected from the Natural Population of the Middle and Eastern Black Sea Region According to UPOV Criteria]. Gaziosmanpaşa Üniversitesi, Fen Bilimleri Enstitüsü, Bahçe Bitkileri Anabilim Dalı, Yüksek Lisans Tezi, Tokat, p: 60. (in Turkish).

Sedighi, E., Rahimmalek, M., 2015. Evaluation of genetic diversity of Rubus hyrcanus using Inter Simple Sequence Repeat (ISSR) and morphological markers. Biologia, 70, 339-348.

Rohlf., 1998. Numerical Taxonomy Multivariate Analysis System, NTSYS-pc version 2.11X, Exeter Software, Setauket, N.Y. USA, 